\title{
Reseña de publicaciones
}

\section{Barcelona, destinació turística. Un segled'imatges $i$ promoció pública}

\author{
Saida Palou i Rubio
}

ISBN: 978-84-938514-1-5

\author{
Dolors Vidal-Casellas* \\ Neus Crous-Costa***
}

Universidad de Girona, España

El estudio de la imagen turística, aun siendo un campo relativamente nuevo dentro de la turismología, se ha dotado de un gran impulso en los últimos años. Ya a finales de la década de 1970 Miossec defendía que una destinación turística no es sino una imagen, una representación mental. Debe asumirse que no se trata de imágenes inocentes y que están cargadas de las ideologías de sus promotores. Teniendo en cuenta la propia naturaleza del hecho turístico (en el sentido que es producido y consumido en el mismo lugar y en el mismo momento) hace que un paisaje turístico no exista antes de crear esta representación (Chadefaud, 1987). Así, la industria del turismo tiene en sus bases la producción, distribución y comercialización de imágenes (Pereiro, 2011). A principios del siglo pasado, Muntañola defendía que el prestigio de un territorio depende de su prestigio turístico.

Como se describe en el estudio realizado por Palou, este proceso es especialmente cierto en el caso de la ciudad de Barcelona, tercer destino urbano Europeo y vigésimo en el mundo de acuerdo con los datos de Euromonitor International (2013). Cuando en 1906, la Comisión de Atracción de Forasteros y Turistas (CAFT) empezó sus actividades, la ciudad estaba desprovista de lo que hoy llamaríamos un producto turístico e, incluso, de una conciencia política y social suficiente. A pesar de las críticas recibidas y de su corta vida, la CAFT invirtió muchas energías en la creación de la imagen turística, seductora y distintiva, de la ciudad, que sentó las bases de la que con el tiempo se convertiría en la marca conocida a nivel internacional.

En el conjunto de la investigación turística, por diversos motivos, el pasado es una cuestión que queda casi siempre relegada a un segundo o tercer término. Palou aporta una detallada descripción de las políticas turísticas públicas que se dieron a lo largo del siglo XX (1888 - 2010, en realidad) y que fueron las que han ido configurando la destinación que hoy en día conocemos y promovemos.

Una de sus aportaciones es la desmitificación, hasta cierto punto, de la presentación de Barcelona al mundo a partir de los Juegos Olímpicos que acogió en 1992. Como ya se apuntaba en la tesis de Vidal (2005), el estudio histórico nos muestra como en el primer tercio del siglo

* Universidad de Girona, España. E-mail: dolors.vidal@udg.edu

** Universidad de Girona, España. E-mail: u1055773@correu.udg.edu 
XX la ciudad ya ocupaba un importante posicionamiento en el imaginario turístico no sólo a nivel europeo, sino también internacional, con una imagen basada en la modernidad (Novecentismo, Modernismo; desarrollo industrial), el patrimonio cultural tangible e intangible, el comercio, el paisaje y el ambiente urbano. Como vemos, se trata de un imaginario que coincide plenamente con el que se proyecta hoy en día.

La mirada histórica, en palabras de la autora $<<$ sorprende (...) [que] descubra más continuidades y similitudes en las estrategias de promoción y en sus argumentos que no diferencias o rupturas >> (p. 19).Precisamente los valores públicos así como los elementos que conforman la imagen de la destinación son los que se han mantenido más regulares a lo largo de esta centuria, exceptuando el período franquista.

La publicación se estructura en cinco grandes bloques, correspondientes a las cinco etapas de la historia (turística) de Barcelona. El primer capítulo nos sitúa en el cambio de siglo: a modernización en la planificación de la ciudad (Pla Cerdà), la Exposición Universal de Barcelona (1888), la llegada de los primeros turistas y el nacimiento de la primera institución turística española, la Comisión Nacional de Turismo. Estos elementos, así como la actuación del sector privado, vieron los cimientos de la industria turística local, que empezaría a desarrollarse con la Comisión de Atracción de Forasteros y Turistas.

El segundo capítulo empieza con la creación de la CAFT (1906), uno de cuyos objetivos principales era la creación de una imagen turística. Para tal fin, poco después de su creación se publicó la primera guía turística de la ciudad para presentarla tanto en su entorno cercano como en el extranjero. Para esta primera piedra en la promoción, París constituía el paradigma a seguir. A partir de entonces, la publicación de materiales de propaganda siguió: carteles, álbumes, guías, artículos en prensa nacional e internacional, agencias de viajes. Pronto, en 1908, la CAFT fue sustituida por la Sociedad de Atracción de Forasteros (SAF), creada a imagen de los sindicatos de iniciativa turísticos ya existentes en Europa, y que tendría una vida mucho más prolongada: moriría en 1936, unos meses después del estallido de la guerra civil. La actuación de la SAF se definía como desinteresada y patriótica. Además, su actuación acabó por rebasar los límites urbanos e intervino en el despertar turístico de otras poblaciones catalanas, por ejemplo, a través de la puesta en valor de monumentos y paisajes del resto del territorio y promoviendo el resto del territorio catalán como posibles destinos de excursiones.
El tercer bloque nos sitúa en el marco de la II República Española (1929 - 1936). La ciudad experimentó transformaciones urbanísticas y de organización turística de importancia significativa. Se crearon diversas entidades de promoción turística, se celebraron exposiciones y salones internacionales y se llevaron a cabo estrategias de gestión. A principios de 1930 Catalunya aparecía en el imaginario como un destino diferenciado, y todo el período fue especialmente fructífero por lo que respecta a la promoción y gestión turísticas (en 1935 más de 240.000 forasteros habían visitado la ciudad). Catalunya y Barcelona no se presentaban como destinaciones antagónicas, sino, al parecer de los propios gestores y promotores.

El cuarto período nos sitúa al inicio de la guerra civil española y la dictadura franquista posterior. El conflicto bélico y el régimen político que la siguió constituyeron un verdadero barrido, tabula rasa como lo llama la autora, de todas las acciones emprendidas hasta ese momento en Barcelona y el conjunto de Cataluña. Todas las actividades pasaban a centralizarse desde la capital del estado, incluyendo, por supuesto, la gestión y la propaganda turísticas. La imagen de modernidad y diferenciación del resto de la península proyectada hasta entonces se diluyó completamente y el imaginario vinculado a Barcelona se adhirió, por fuerza, al imaginario estereotipado de España. El boom turístico se aconteció en esta época, gobernada por el desorden y la anarquía. Como se describe en el libro $<<$ la regla principal del sistema se basaba en un se salve quien pueda, juego pernicioso que hacía ganar dinero a base de tierras que no valían nada, permitía que las cabañas de pescadores se convirtieran en hoteles, mientras los hortelanos vendían tomates a precio de oro (...) $>$ (p. 271). Sin duda, el turismo fue también un instrumento político: el desarrollismo primaba el aumento de visitantes, la entrada de divisas y el crecimiento del negocio, a la vez que se proyectaba una imagen de España unificada e identitariamente homogénea.

Para terminar, el quinto capítulo se refiere a lo acontecido durante la transición democrática, heredera de los perjuicios y prejuicios de la era anterior, y llega hasta nuestros días. Como reconoce Palou, a principios de la década de 1980 todavía era difícil confiar en las potencialidades de Barcelona como destinación turística: su reconocimiento internacional estaba desdibujado, la oferta no era suficientemente competitiva y, al contrario que en etapas anteriores, competía con la destinación Catalunya. Varios cambios ocurridos a finales de esa década y a principios 
de la siguiente, entre los que destacan la preparación para los Juegos Olímpicos (1992) dieron un impulso renovado al sector turístico $\mathrm{y}$, volviendo de forma no consciente a las políticas de principios de siglo, las políticas actuales de internacionalización de la ciudad identifican al turismo como un sector clave para la captación de capital económico y cultural. Este crecimiento ha generado en los últimos años problemas de saturación y la necesidad de un replanteamiento de la estrategia a seguir. El libro nos deja en este nuevo punto de inflexión, con la redacción del Plan Estratégico de Turismo de la Ciudad de Barcelona y la necesidad de gestionar el crecimiento de esta industria.

A través de este libro, Palou nos ofrece una visión transversal de la historia del turismo en la ciudad de Barcelona a lo largo de más de cien años, ejercicio harto interesante tanto desde el punto de vista de los propios gestores como de los académicos dada la ausencia de trabajos previos en esta línea tanto a nivel local como internacional. El ejemplo de Barcelona, estudiado por turismólogos de todas las partes del planeta, toma aquí otra perspectiva, más rica, compleja y concreta.

\section{Referencias}

Chadefaud, M.

1987 Aux origines du tourismedans les Pays de l'Adour: du mythe à l'espace: un essai de géographiehistorique. Pau: Département de géographie et d'aménangement de l'Université de Pau et des Pays de l'Adour: Centre de Recherche sur l'impact socio-spatial de l'aménagement.

Euromonitor International.

2013 Top 100 Cities Destination Ranking. Recuperado 20 mayo 2013, desde http:// blog.euromonitor.com/2013/01/top-100-cities-destination-ranking.html

Miosec, J.M.

1976 Elementspour une theorie de l'espacetouristique. Aix-en-Provence: Centre des Hautes ÉtudesTouristiques.

Muntañola, A.

2004 Organització turística de Catalunya. Barcelona: Turisme de Barcelona, 2004. Barcelona: ArtsGràfiquesL'Estampa, 1932. [Facsímil]

Pereiro, $\mathrm{X}$.

2011 "El turismo como patrimonio cultural imaginario. Reflexiones a partir del caso de turismo kuna (13-26)". En Prats, L., Santana, A. (coord.). Turismo y patrimonio. Entramados narrativos. El Sauzal: Pasos edita. 